\title{
THE ROLE OF AGROTOURISM \\ IN A COUNTRY DEVELOPMENT \\ WITH REGARD TO WOLIN COMMUNITY
}

\author{
EWA SZCZEPANOWSKA, ${ }^{1}$ MAŁGORZATA ZABIELSKA ${ }^{2}$
}

${ }^{1}$ University of Szczecin, POLAND

e-mail: ewa.szczepanowska@univ.szczecin.pl

2 e-mail: lichowskamalgorzata@wp.pl

RECEIVED
ACCEPTED

JEL

CLASSIFICATION

KEYWORDS

ABSTRACT
20 April 2018

12 July 2018

Q5, Q55

agrotourism, Wolin community, determinants of country development

The aim of work is to determine agrotourism role in a country development in regard to Wolin community and to indicate agrotourism development determinants with connections between them.

The number of 20 agrotouristic household owners at the age 30-69 y.o. is studied. The bulk of households $(65 \%)$ is carried on by women at the age 50-59 y.o. The method of diagnostic poll and the Pearson's $X^{2}$ test to data analysis are used.

In opinion of the majority of contractors (75\%) the agrotourism development advantageously influences on the country development. The only significant dependence $\left(p=0.09520^{\star}\right)$ between the period of the activity management and the evaluation of agrotourism development possibilities in Wolin community is noticed.

One can conclude that longer period of the agrotourism activity management causes more positive note of economic and social development of the country. In opinion of agrotourism household owners, Wolin community is characterized by many natural and cultural attractions, as a basis for the agrotourism development and a stimulus for potential tourists. Respondents notice also the activity of local government engagement in the agrotourism development and seek in this phenomenon a chance to a further development.

\section{Introduction}

Agrotourism from the beginning of 1990s underlies a very intensive quantitate and qualitative development. This phenomenon is a result both of government policy and an increasing demand for this kind of services. Since many years there is a very popular form of spending holidays in Western Europe. Its adaptation in Poland, rich 
tradition connected with "holidays under pear", and also economic needs of farmers cause a very favorable situation to the further development (Knecht, 2009, pp. 162-164).

The relation of local government to agrotourism determines the intensity of supporting this form of activity but very often the limited possibilities of tourism financing by local government are the reason of state assistance in agrotourism development (Szostak, 2006, p. 174). Invaluable the assistance from touristic organizations or foundations is, as well. The whole idea requires future thinking; it means a strategy to create tourism development at the state and regional level. Country tourism besides resting and recreational tourism is distinguished as a one from the branded touristic product of the region (rsi.org.pl/dane/download/ strategia_2015.pdf, p. 31).

As the basic determinants of agrotourism development it can be recognized natural and landscape attractions due to their appropriable and esthetic functions. Anthropogenic attractions, infrastructure, communication availability, temper and hospitality of local population and householders are likewise important (Przezbórska, 2007, pp. 114-115). The care of natural and socio-cultural environment with a key role here of an adequate preservation and management of natural resources can be added on the top (Gołembski, 2009, p. 360).

A leading function of Wolin community is food economy because of a relatively high percentage of utilized agricultural area. There is $43.7 \%$ of its area, and forests and forest lands $-22.7 \%$. Small households to $15 \mathrm{ha}$ outweigh. The half of Wolin community territory, with Wolin National Park (WNP) as a neighbor, is located at the Wolin Island. It is split up from the land by Dziwna River sound (bip.wolin.pl, 12.03.2017). Tourists visiting the community can use valuable and unique attractions and virtues (e.g. two nature reserves: Łuniewo and Wiejkowski Forest). The season lasts to 180 days because it is the sunniest region of Polish seaside in summer months (Pieczyński, 2004, pp. 149-150).

Immensity of anthropogenic attractions of Wolin community owes a very long and turbulent history of this area. There are many heirlooms from the far-distant past of this area at this territory. The settlement development is dated to the VIII-X century. In the XIX century geological layer of chalk are discovered at this area. Natural chalk causes the concrete industry development. The souvenir of a chalk mining excavation, very popular among tourists, is Turkusowe Lake in Wapnica village. Commencement of tourism development at this area is estimated for the half of XIX century with the recognition of seaside climate possibilities and richness of natural and anthropogenic attractions (Grzegorczyk, Lewicki, 2004, pp. 9-10).

The aim of work is to determine agrotourism role in a country development in regard to Wolin community and to indicate agrotourism development determinants with connections between them.

\section{Method}

The number of 20 agrotouristic household owners (women - W and men - M) at the age 30-69 y.0. is studied (Table 1). The bulk of households (65\%) is carried on by W at the age 50-59 y.o. Respondents have the high (40\%), secondary (40\%) and professional (20\%) level of education. 
Table 1. Respondents' gender, age and an education level

\begin{tabular}{lccc}
\hline \multicolumn{1}{c}{ Age } & $30-49$ y.o. & $50-59$ y.o. & $60-69$ y.o. \\
\hline$W(n=13)$ & 4 & 6 & 3 \\
$M(n=7)$ & 2 & 4 & 1 \\
Level of education & Professional & Secondary & High \\
$W(n=13)$ & 3 & 6 & 4 \\
$M(n=7)$ & 1 & 2 & 4 \\
\hline
\end{tabular}

Source: own elaboration.

The method of diagnostic poll with the tool of a questionnaire and the Pearson's $\chi^{2}$ test to data analysis are used.

\section{Results}

The bulk of agrotouristic households are in villages near the border of WNP, in the central part of Wolin Island. Among respondents the greatest group (80\%) of households is active above 5 years (Figure 1).

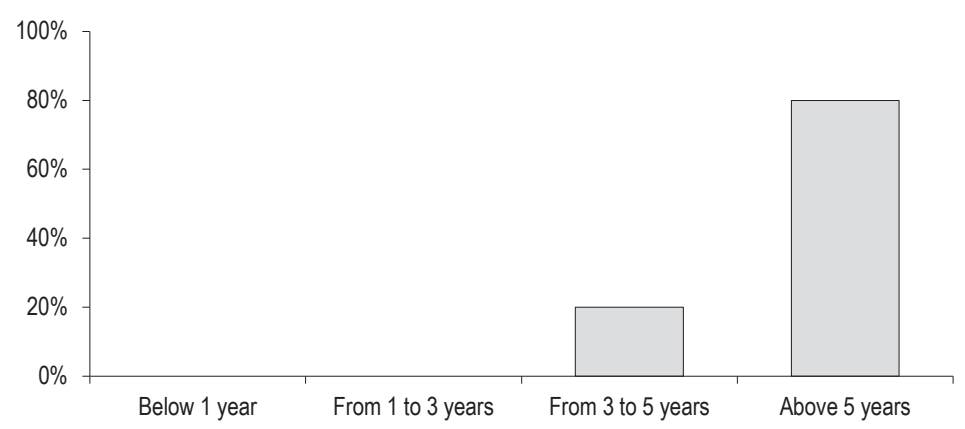

Figure 1. The period of agrotouristic activity management

Source: own elaboration.

The main motives of undertaking the agrotouristic activity management by populace of Wolin community economic determinants are (52\%) (Figure 2), then a will to master the second profession (29\%), also this kind of reason as bailout from the SAPARD program, contact with other people and broadening of contacts or passion and pleasure with the management of this activity $(13 \%)$. 


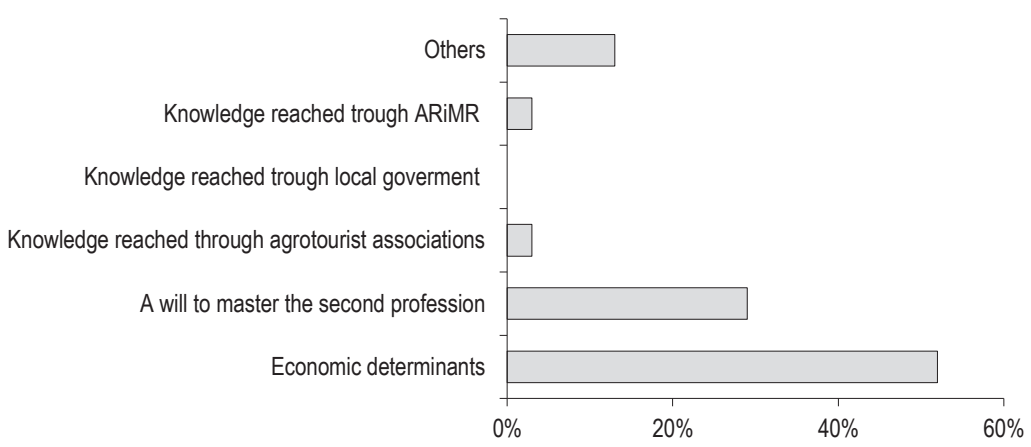

Figure 2. Reasons of undertaking the agrotouristic activity management

Source: own elaboration.

The evaluations of conditions and possibilities of agrotourism development in Wolin community are advantageously distributed, distinctly at the good notes (55\%) and very good notes side (10\%) (Figure 3).

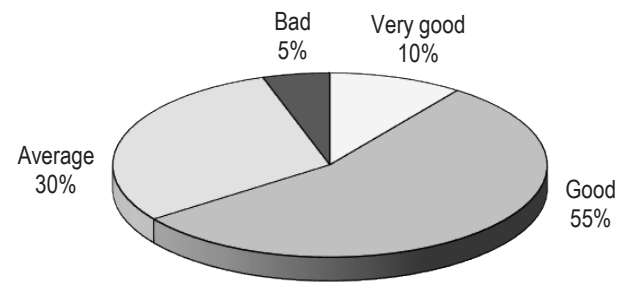

Figure 3. The evaluation of conditions and possibilities of agrotourism development in Wolin community Source: own elaboration.

Agrotouristic households in Wolin community in majority (80\%) have over 9 accommodation places; there are big objects (Figure 4).

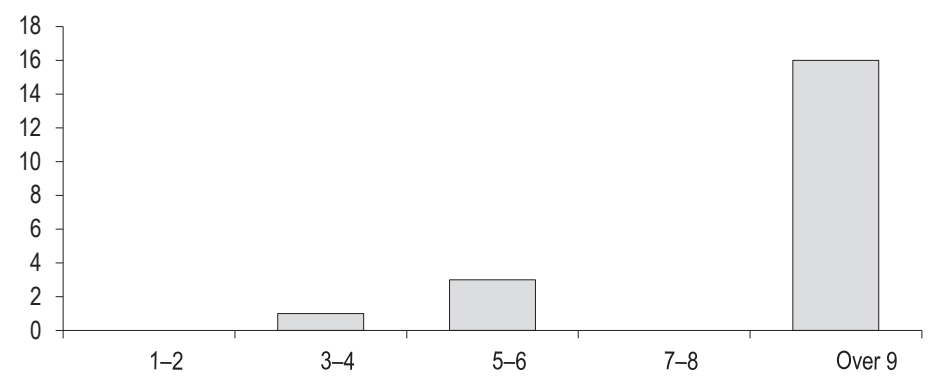

Figure 4. The number of accommodation places in agrotouristic objects

Source: own elaboration. 
Among households $60 \%$ is active the whole year (Figure 5). It is due to many attractions and services offered by households, and also anthropogenic and natural attractions interesting beside the season, as well. From May to September $30 \%$ of studied households are open.

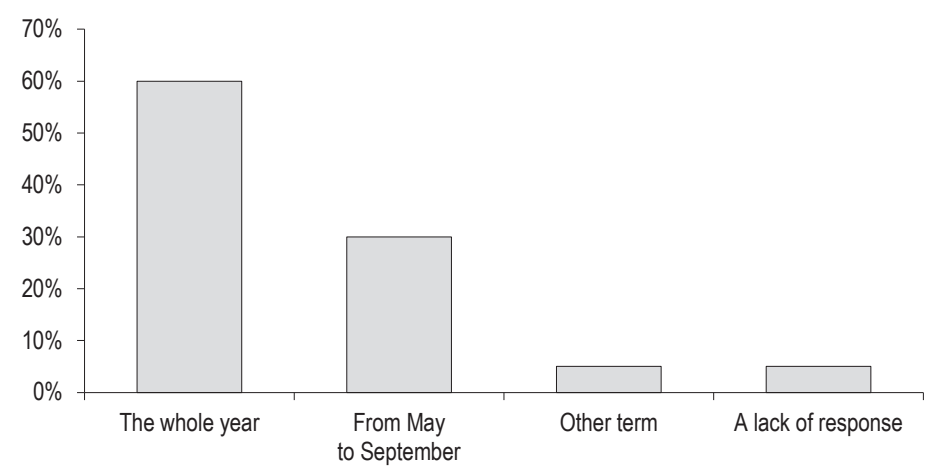

Figulp 5. The period of agrotouristic objects availability in Wolin community

Source: own elaboration.

In $95 \%$ of objects tourists stay one week and they do not decided to stay shorter, or for weekend and longer stays, embracing time to month or longer.

The offered accommodation basis in studied objects is much differentiated (Table 2). There are mainly rooms in a residential building of household owners $(40 \%)$, static caravans $(26 \%)$, also rooms in a separate building (17\%) and tent fields (17\%).

Table 2. The form of the accommodation basis offer

\begin{tabular}{lcc}
\cline { 2 - 3 } & $\mathrm{n}$ & $\%$ \\
\hline Rooms in residential building of household owner & 12 & 40.0 \\
\hline Rooms in a separate building & 5 & 17.0 \\
\hline Static caravans & 8 & 26.0 \\
\hline Tent fields & 5 & 17.0 \\
\hline
\end{tabular}

Source: own elaboration.

To $51 \%$ of households mainly families with children come, and $45 \%$ of households is visited by individual tourists (Figure 6). Only $14 \%$ of households receive organized groups. 


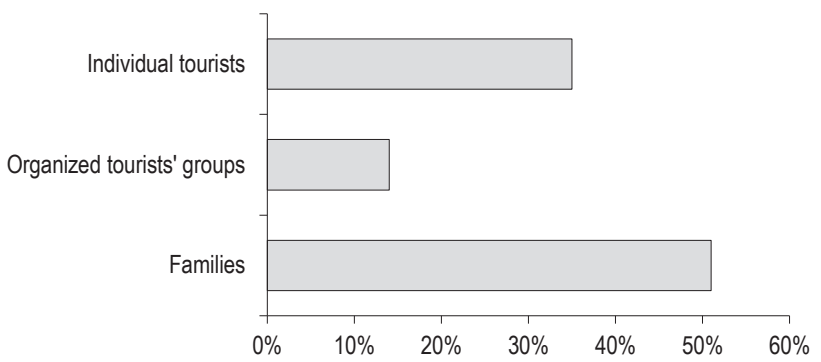

Figure 6 . Guests' groups the most often using the agrotouristic households services

Source: own elaboration.

The main attractions offered by $85 \%$ of households are feasts (Figure 7). At the area of WNP there is a prohibition of mushrooming but the half of household owners have in their offer mushrooming in forest concentrations besides WNP. Many lakes enable fishing being attraction of $50 \%$ agrotouristic objects; in $20 \%$ of them are stables, and $30 \%$ - horse riding. It can show the collaboration of particular household owner or using in an offer the same horse riding object by a few households. Only $5 \%$ among respondents offer surrounding sightseeing with guide; there is not amid them a requirement for this kind of services because touristic trails and objects are good labelled and described, and tourists prefer individual sightseeing. The participation in household works should be a flagship attraction of each agrotouristic household; there is not only in 15\% of objects' offer in Wolin community.

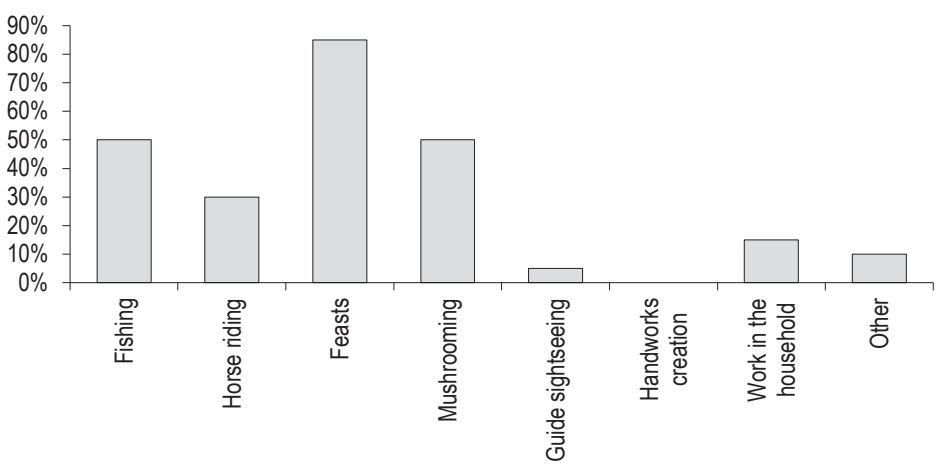

Figure 7. Attractions offered in agrotouristic households in Wolin community

Source: own elaboration.

In opinion of $27 \%$ respondents the main determinant encouraging tourists to benefit from an offer is a household localization (Figure 8). Objects are located along WNP, and an important trump is also the nearness of Baltic Sea and communication availability. Determinant whipping up an interest of potential clients are surrounding attractions (24\%), only $14 \%$ of respondents recognize household's attractions as the most important element activating tourists. It can show on underinvestment in objects infrastructure. For $17 \%$ of respondents the determinant attracting tourists to their household is a marketable price and a high service level (16\%), as well. 


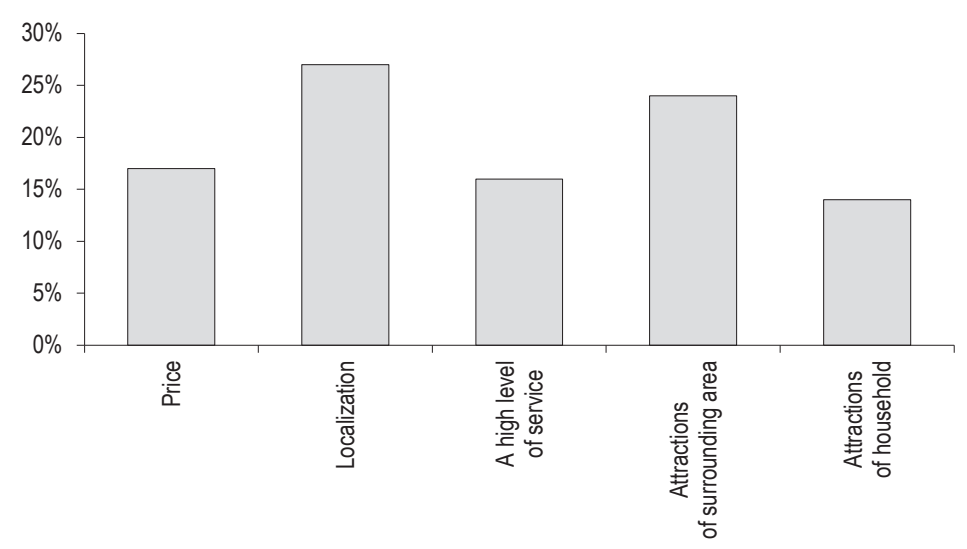

Figure 8. Determinants encourage benefiting from an agrotouristic households' offer in Wolin community Source: own elaboration.

Mainly, a success of agrotouristic household is dependent on a good promotion and marketing. The majority (74\%) of household owners use a promotion in internet (Figure 9). The compensating form of advertisement used by household owners are folders, touristic catalogs, a collaboration with a travel office or press information, $5 \%$ of households take an active part in tourist fairs, and only for $5 \%$ of respondents guests' recommendations are essential.

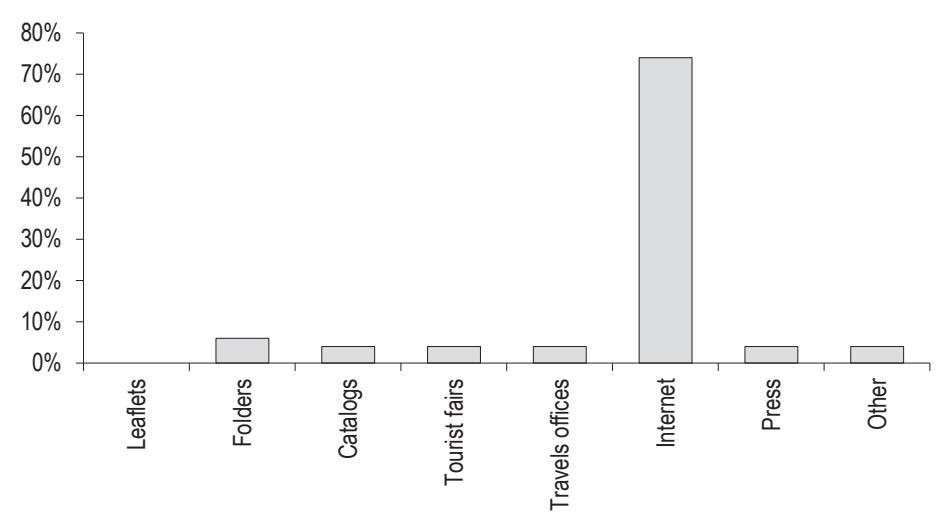

Figure 9. Ways of agrotouristic objects promotion

Source: own elaboration.

The majority (75\%) of respondents recognize an agrotouristic activity management as a determinant positively influencing on the development of their place of residence (Table 3), and for $20 \%$ there is a lack of an influence. Respondents bracket additional incomes for agrotouristic household owners and inhabitants (20\%) to positive elements of agrotourism development through encouraging a demand of goods and services, also of not quite 
touristic character. A tourists' inflow impose from household owners, local government and the rest of inhabitants the increase of the locality esthetics care (15\%). Among respondents $5 \%$ pay attention on the transformation of countryside role from agricultural to touristic (Table 3).

Table 3. The influence of agrotourism on the village development

\begin{tabular}{lcc}
\hline & $\mathrm{n}$ & $\%$ \\
\hline The lack of an agrotourism development influence on the locality development & 4 & 20 \\
Incomes for inhabitants & 4 & 20 \\
The increase of the locality esthetics care & 3 & 25 \\
The village advertisement & 1 & 5 \\
The locality infrastructure development & 1 & 5 \\
The promotion and locality development & 1 & 5 \\
The excitement of demand for goods and not quite touristic services & 1 & 5 \\
The transformation of countryside role from agricultural to touristic & 1 & 5 \\
The good influence of agrotourism development on the locality development & 1 & 5 \\
\hline
\end{tabular}

Source: own elaboration.

The household owners evaluation of the surrounding touristic infrastructure hesitates from very good $(16 \%)$, through average (13\%), to weak (16\%) (Table 4). In opinion of respondents $24 \%$ show on negative sides of the surrounding touristic infrastructure (Table 4), for $9 \%$ of respondents internal roads are in a bad condition, and $6 \%$ of household owners show the lack of bike routs or the lack of trails, in general (3\%), despite many indicated bike and pedestrian trails at the Wolin community area. However, respondents show also on engagement of the local government in improvement of the infrastructure and the locality esthetics care (13\%), good roads (3\%) and an improvement of communication infrastructure (6\%) (Table 4).

Table 4. The household owners evaluation of the surrounding touristic and paratouristic infrastructure status

\begin{tabular}{lcc} 
& $\mathrm{n}$ & $\%$ \\
\cline { 2 - 3 } & 5 & 16 \\
Very good & 4 & 13 \\
Average & 5 & 16 \\
Weak & 3 & 9 \\
Bad status of the village internal roads & 1 & 3 \\
The lack of trails & 2 & 6 \\
The lack of bike trails & 1 & 3 \\
The lack of refuse dumps & 1 & 3 \\
The lack of benches & 4 & 13 \\
Community investments in infrastructure, community care of the locality esthetics & 1 & 3 \\
Good roads & 2 & 6 \\
The improvement of communal infrastructure & 4 \\
\hline
\end{tabular}

Source: own elaboration. 
In accordance to $X^{2}$ Pearson test results (Table 5), despite many examined determinants, there is the significant dependence only between the period of the activity management and the evaluation of agrotourism development possibilities in Wolin community $\left(p=0.09520^{*}\right)$. It is connected most likely with the brand recognition at agrotouristic objects and their household owners.

Table 5. The significance of $\chi^{2}$ test calculation

\begin{tabular}{|c|c|c|}
\hline & \\
\hline & $x^{2}$ & p \\
\hline Gender/age & 0.53333 & 0.76593 \\
\hline Gender/education level & 5.34799 & 0.25342 \\
\hline Gender/availability to agrotouristic objects & 2.42347 & 0.11953 \\
\hline Gender/period of agrotourism activity management & 0.21978 & 0.63921 \\
\hline Gender/groups the most often using services (families) & 0.56680 & 0.45153 \\
\hline Availability of agrotouristic objects/evaluation of agrotourism development possibilities & 4.66158 & 0.19832 \\
\hline Availability of agrotouristic objects/number of accommodation places & 2.07813 & 0.35379 \\
\hline Number of accommodation places/evaluation of agrotourism development possibilities & 3.15657 & 0.78896 \\
\hline Period of activity management/availability of agrotouristic objects & 0.30536 & 0.58054 \\
\hline Period of activity management/evaluation of agrotourism development possibilities & 6.36364 & $0.09520^{*}$ \\
\hline
\end{tabular}

A level of statistical significance ${ }^{*} p \leq 0.1$.

Source: own elaboration.

\section{Discussion}

The Wolin community is a very attractive area to agrotourism development in regard to richness of natural and cultural virtues and the nearness of Germany, as well. In particular agrotourism can decides on a development of little households, located at the area rich in natural and cultural virtues, with limited possibilities of development and competition in the market (Krupińska, 2003, pp. 161-162; Bórawski, 2010, p. 25; turystyka.pb.edu.pl, 9.03.2017).

The increasing interest of undertaking agrotourism management is caused not only by the growth of touristic services but also the looking for new ways of development, possibilities of activating poorly develop territory and threated by hidden unemployment in agriculture (Kozak, 2009, p. 9). In this work motives of undertaking agrotourism activity management are mainly economic (Figure 2, Table 5).

Different conditions of agrotourism development arise from the place of agriculture in development of this area, demographic structure, situation at the labor market, local government and populace activity, and from local population skills and tradition, as well (Sikorska-Wolak, 2004, p. 13). They are exposed at the Wolin community area and can be result of differences in existing infrastructure status, and also rate and frequency of modernizations in particular localities. Among respondents $20 \%$ do not see the agrotourism influence on the community development, and so $75 \%$ of them introduce the positive opinion (Table 5). The discrepancy of opinions can be a result of provided till now investments at the Wolin community area. Villages, like Kołczewo or Wisełka can display the rich touristic and paratouristic infrastructure, whereas in Warnowo or Jagienki there is even a lack of asphalt roads.

Amid conditions of agrotourism development natural and anthropogenic virtues take immeasurably important place. Undertaking agrotouristic activity management household owners are than obligated to broaden their knowledge, not only in management and marketing of the firm but also attractions and history of their own region 
to make potential tourists interested in the community (turystyka.pb.edu.pl, 9.03.2017). Knowledge of particular agrotouristic household owners is much differentiated (Table 4), 6\% from them do not know there are bike routs in Wolin community, and $3 \%$ - consider that there are no trails at all. It is false because Wolin community abounds in bike and pedestrian trails (Pieczyński, 2004, pp. 149-150).

The best advertisement for agrotourism household is the opinion of satisfied guests visiting a given household and can inform about its trumps further guests (insightmarketing.eu/publikacje/promocja-i-dystrybucja-uslugagroturystycznych-w-wojewodztwie-podlaskim, 12.03.2017). Unfortunately, this way of household promotion is unappreciated by household owners in Wolin community because only $5 \%$ of respondents consider that guests recommendations have an essential meaning in the object promotion (Figure 9). It accentuates also the aspect connected with impediments for single households because the promotion requires adequate qualifications and knowledge, also financial means and help from agrotourism associations or agricultural consultancy centers. Unfortunately, in Wolin community only $5 \%$ of households belong to agrotouristic association and have a category given by Polish Federation of Country Tourism "Gospodarstwo Gościnne" "Hospitable Household" (Drag, 2003, pp. 129-131; agroturystyka.info.pl, 26.12.2017). It can be caused by a fear of difficulties in managing to impose category requirements or from ignorance of agrotouristic household owners about profits from membership in this kind of association. The low interest of respondents to touristic fairs (4.0\%) corresponds with household owners belongingness to agrotouristic associations.

In opinion of $5 \%$ of agrotouristic household owners in Wolin community agrotourism causes the change of role till played by localities, a wit a transition from the agricultural to touristic function (Table 5). This phenomenon goes by the change of residential to resting-recreational space, and as the years go by the touristic role dominates on agricultural production (Wojciechowska, 2009, pp. 18-22). This aspect is noticed by $15 \%$ of respondents. Agrotourism influences also on the range of material and non-material social advantages, as the village infrastructure modernization, the implementation of new touristic investments, with the contribution to modernization of agrotouristic households, the village and the community (turystyka.pb.edu.pl, 9.03.2017). For $5 \%$ of respondents this aspect is important. They consider that agrotourism development in their locality contributes towards the village infrastructure expansion (Table 3).

Possibilities of agrotourism development are related mostly to the period of the activity management (Table 5). It is connected with the brand building and recognizability of a given household. It contributes at the end to the development of the surrounding area and increases life level of its localities. It is a great chance of better future for the village inhabitants. It brings a range of positive advantages, and an adequate planning and adjusting its development to natural and cultural environment needs allow neutralizing possible negative effects. Important is also help from the side of local government and organizations as agrotouristic associations for the dynamic development of agrotouristic households because for single household owners it is very difficult to run singlehandedly at the very challenging market.

\section{Conclusions}

The longer period of the agrotourism activity management causes the significant dependence between the period of the activity management and the evaluation of agrotourism development possibilities in Wolin community. In opinion of agrotourism household owners Wolin community is characterized by many natural and cultural values as a basis for the agrotourism development and a stimulus for potential tourists. Respondents notice 
also the local government engagement in the agrotourism development and seek in this phenomenon a chance to a further development.

\section{References}

agroturystyka.info.pl.

bip.wolin.pl.

Bórawski, P. (2010). Finansowanie działań umożliwiających pozyskiwanie alternatywnych źródeł dochodów przez właścicieli gospodarstw rolnych. Acta Scientiarum Polonorum Oeconomia, 9 (3), 25-34.

Drąg, K. (2003). Działania Polskiej Federacji Turystyki Wiejskiej „Gospodarstwo Gościnne” na rzecz rozwoju i promocji turystyki wiejskiej w Polsce. Zeszyty Naukowe Akademii Rolniczej im. H. Kołtątaja w Krakowie, 402, 129-131.

Gołembski, G. (ed.) (2009). Kompendium wiedzy o turystyce. Warszawa: Wydawnictwo Naukowe PWN.

Grzegorczyk, K., Lewicki, I. (2004). Woliński Park Narodowy kraina różnorodności. Międzyzdroje: Woliński Park Narodowy. insightmarketing.eu/publikacje/promocja-i-dystrybucja-uslug-agroturystycznych-w-wojewodztwie-podlaskim.

Knecht, D. (2009). Agroturystyka w agrobiznesie. Warszawa: C.H. Beck.

Kozak, M. (2009). Turystyka i polityka turystyczna a rozwój: między starym a nowym paradygmatem. Warszawa: Scholar.

Krupińska, W. (2003). Uwarunkowania rozwoju agroturystyki w województwie zachodniopomorskim. Zeszyty Naukowe Akademii Rolniczej im. H. Kołłątaja w Krakowie, 402, 161-170.

Pieczyński, L. (ed.) (2004). Wyspa Wolin zrównoważony rozwój w strefie przygranicznej. Szczecin: Oficyna in Plus.

Przezbórska, L. (2007). Determinanty rozwoju agroturystyki w Polsce (na przykładzie wybranych regionów). Acta Scientiarum Polonorum Oeconomia, 6 (2), 113-121.

rsi.org.pl/dane/download/strategia_2015.pdf.

Sikorska-Wolak, I. (2004). Rozwój lokalny jako wielowymiarowe zjawisko społeczno-gospodarcze. In: I. Sikorska-Wolak (ed.), Turystyka w rozwoju lokalnym. Warszawa: SGGW.

szczecin.lasy.gov.pl/web/rokita.

Sznajder, M., Przezbórska, L. (2006). Agroturystyka. Warszawa: PWE.

Szostak, D. (2006). Polityka turystyczna. In: A. Panasiuk (ed.), Ekonomika turystyki. Warszawa: Wydawnictwo Naukowe PWN. turystyka.pb.edu.pl/artykuly.html.

Wojciechowska, J. (2009). Agroturystyka w kreowaniu przestrzeni turystycznej. In: P. Palich (ed.), Marka wiejskiego produktu turystycznego. Gdynia: Akademia Morska.

Cite this article aS: Szczepanowska, E., Zabielska, M. (2018). The role of agrotourism in a country development with regard to Wolin community. European Journal of Service Management, 3 (27/1), 329-339. DOI: 10.18276/ejsm.2018.27/1-42. 